\title{
Changements politiques et pratiques alimentaires au Cambodge
}

Marie Alexandrine Martin

\section{(2) OpenEdition}

1 Journals

Édition électronique

URL : https://journals.openedition.org/tc/388

DOI : $10.4000 /$ tc.388

ISSN : 1952-420X

Éditeur

Éditions de l'EHESS

Édition imprimée

Date de publication : 1 avril 1999

ISSN : 0248-6016

Référence électronique

Marie Alexandrine Martin, «Changements politiques et pratiques alimentaires au Cambodge»,

Techniques \& Culture [En ligne], 31-32 | 1999, mis en ligne le 26 octobre 2005, consulté le 29 septembre 2022. URL : http://journals.openedition.org/tc/388 ; DOI : https://doi.org/10.4000/tc.388

Ce document a été généré automatiquement le 29 septembre 2022.

Tous droits réservés 
Changements politiques et pratiques alimentaires au Cambodge

Marie Alexandrine Martin 